\title{
SOCIOLOGY, POLITOLOGY AND PUBLIC POLICY IN DEVELOPMENT AND MUTUAL RELATIONS IN SLOVAKIA, THE CZECH REPUBLIC AND POLAND ${ }^{1}$
}

\author{
Stanislav KONEČNÝ \\ Associate Professor at the Faculty of Public Administration \\ Pavol Jozef Šafárik University in Košice, Slovak Republic \\ E-mail: stanislav.konecny@upjs.sk \\ Richard GEFFERT \\ Associate Professor at the Faculty of Public Administration \\ Pavol Jozef Šafárik University in Košice, Slovak Republic \\ E-mail: richard.geffert@upjs.sk
}

\begin{abstract}
Public policy, as the youngest of the political sciences, began to take shape in the early 1950 s in the field of political science, particularly in the United States, under the influence of empirical research in the framework of the so called Policy Analysis. The use of sociological methods in this research was one of the factors that shifted political science toward public policy theory, while sociological inspiration was also present in the theoretical plane of this shift (for example, the influence of J. Dewey on H. Lasswell, etc.). Alongside, the American school, in Germany Politikfeldanalysen developed in a partly different direction, and the French politique publique with the strongest influence of sociology. Some attention has already been given to comparing these "national schools" in the development of public policy and its theory in these "classical" countries. The present study compares the course of the interaction between political science, sociology, and public policy in three Central European countries - the Czech Republic, Slovakia, and Poland - where these relations were able to develop only following the establishment of democratic social order in the early 1990s. Both in the Czech and Slovak Republic, during totalitarian political system political sciences ceased to exist and when back in 1990s they were restored, sociologists participated as well, which, in turn
\end{abstract}

\footnotetext{
${ }^{1}$ The paper is part of the outcome of the grant project VEGA 1/0290/20 Social Justice
} and Old-Age Pension Savings in the Slovak Republic. 
had positive impact on the start of public policy within the framework of political sciences. In Poland, however, the politology cal science survived in a format under influence of ideology, but it did not established a framework to give rise to public policy, that was here replaced by other sciences.

Key words: Politology, Sociology, Public Policy, Czech republic, Slovakia, Poland

\section{Introduction}

Public policy theory, as a new social science, (Fischer-Miller - Sidney 2007: xix) began to emerge in the 1950s, when political science, after decades of its development in the mainstream of institutionalism, saw the beginning of a strengthening trend of pluralism, characterised also by a greater inclination toward examining political phenomena empirically. This, together with the use of sociological and psychological methods and techniques, brought other impulses of sociological and psychological thinking to the political science environment (Novotný, 2008, p.18). This is also reflected in the differences in the subject of political science (more specifically Duverger, 1959, 1961) and public policy theory, where highlights include attention paid to political elites (or the political system, or even political parties) versus the attention paid to a much broader spectrum of group (supra-individual) actors (including those outside the political system), or also attention devoted to the phenomenon of power versus attention paid to (public) interests. The differences in these two parameters already indicate a more empirical and sociological (or at least sociologising) nature of public policy theory compared to political science, from which the theory of public policy unquestionably originated.

However, sociology was already present in the emergence of public policy theory, to some extent by the simple use of sociological methods and techniques, as well as directly in identifying its subject. Harold Lasswell, considered to be the founder of public policy (Malíková, 2003, p.17, Fischer Miller - Sidney 2007: xix and others), is known to have been interested in the work of John Dewey (Torgerson 2007), especially in his work on public issues (Dewey, 1927), but we could also trace here the influence of the work of G. Tarde, distinguishing collectivity from aggregate (cohue), through the crowd (foule), audience (auditoire) to the public (Tarde 1989: 21), and other representatives of particularly the Nedurkheim line in the development of sociology.

In various countries, the influence of sociology, especially political sociology (̌́íchová, 2000, p. 25), on shaping public policy theory is different. 
Sociology, politology and public policy in development...

This is one of the reasons why differences in the profile of this new science public policy, as well as in politology; political science or political sciences, arose, especially in the American, German and French spheres. For example in the Francophone version of public policy theory this influence was manifested not only in the very early study of the relationship between these two sciences - sociology and public policy (Bourricaud, 1958), or currently in the publications by Michel Crozier and his Centre de sociologie des organisations (Novotný, 2008, p. 9), but still today both the sociology of politics, as well as political sociology are much more integrated in the system of political sciences there than in other European countries (Novotný, 2006, Muller, 2009) including, for instance, Slovakia, where the sociology of politics (Stena, V. Krivý) is perceived as a branch sociological discipline, rather than as a part of the system of political sciences. It was precisely for this scientific volatility that U. von Allemann termed political sociology "ein wissenschaftliches Chamäleon" (Alemann, 1998, p. 3), but yet again this is just an assessment from the position of the German Politikfeldanalyse. There is, though, a lack of comparisons concerning the development in this area - unless we count comparisons of individual countries with the approach of American public policy (Novotný, 2008, p. 3), something which we have attempted - particularly in the Czech - Slovakia - Poland relationship, in this study, at least in one aspect concerning the relationship between sociology and the still new public policy theory.

It is not our ambition to present here historiographically complete (exhausting) and accurate overview of the development of our, Slovak, (let alone Polish) sociology and political science, but rather to think mainly about the importance of the fermenting influence of sociology on the development of public policy in the womb of political science here, in Slovakia, (and in the Czech Republic), or about other forms of this influence in Poland. Thus, our method will not be historiography, but rather comparative studies comparative method, although with some features of historiographic comparatitive studies.

1 Starting points of the formation of sociology and political sciences in Czechoslovakia and Poland in the 1950s through 1980s

Sociology entered the development of political sciences in a special but different way in the post-war period in the countries of the post-Soviet bloc. Particularly after the Second World War, the free world enjoyed the charm of political plurality not just in practice but also in the theory of social sciences, in these countries, the social sciences were ruled by ideological dominance of historical materialism and so-called scientific communism. Even geographically close countries were not affected by this deformation equally, or even for the same duration of time. Yugoslavia probably fared best, where social science thought experienced at least a partial development, especially on 
the pages of the critical journal Praxis, published by the Faculty of Humanities and Social Sciences of the University of Zagreb, the sociologist Rudi Supek being an example. But, even the most important representative of Yugoslav political science, Milovan Dilas, one of fathers of the so-called third way theory, did not escape reprisals. Experiments in Hungary met similar fates, e. g. in the person of sociologist Iván Szelényi (Antal, 2019).

The turbulent history of Czechoslovak sociology in the post-war decades up to 1990 is sufficiently known and now evaluated in both parts of former Czechoslovakia; in Slovakia (Szomolányiová, 1995, Falt’an 1995, Roško 1995, more recently Klobucký, 2009, Laiferová-Mistríková 2014, etc.), including Bohemia and Moravia (Janišová - Ullrich, 1998, Nešpor et al., 2014, especially Pecka, 2011, Musil, 2004, Sedláček, 2004, Možný, 2004, Skovajsa - Balon, 2017, etc.). After being ideologically liquidated as a separate science in Czechoslovakia in the period after 1948 and following decades of previous promising development, it began to revive after 1956 under various guises, with a view to attempting to develop more freely in 1964 - 1968, despite the persisting grip of Marxist ideology, and in the following two decades to actually functioning freely (also in terms of methodology), particularly in emigration or in dissent, in the well-known "islands of positive deviation".

As far as political science is concerned, in Czechoslovakia modern political science did not even have time to fully form following the Second World War. Finally, even in the UNESCO publication published in connection with the founding of the World Political Science Association (Salvadori, 1950), containing dozens of chapters on the state of development of political science in various countries of the world (including, for example, India and Argentina), Czechoslovakia no longer even had such a chapter. (A major publication in the formation of political science, as an autonomous scientific discipline in a global context, was the publication by M. Duverger from 1959). The rise of political science in Czechoslovakia during the time of the Prague Spring was that much more pungent, yet short-lived. Nevertheless, the inscription of Department of Political Science on the door of several rooms in the building of the Faculty of Arts of Comenius University, which hung there proudly at the beginning of the 1968-69 academic year, i.e. following the August occupation, was retained as an internal identity by many of its students and numerous teachers of that time, despite having soon after been replaced by the inscription of Department of Scientific Communism... A similar story from the environment of the Faculty of Arts of Charles University in Prague is related by M. Novák (2011b, p. 31).Even the first local textbook of political science, published by Jan Škaloud in 1969 at the Epoch publishing house (Škaloud, 1991, p. 5), was instantly blacklisted in "index of defective literature". Political science in Slovakia in the period of "normalisation" was not allowed to even exist under its own name. It 
Sociology, politology and public policy in development...

must though be admitted that sociology, returning to the scene only shortly before the period described above, did not have time to participate to any greater extent in this brief history of the birth and relapse of political science in Czechoslovakia. Representatives of that short political history (Z. Mlynáŕ, M. Kusý ...) also soon fell into disfavour.

The development of sociology, and also political science, in neighbouring Poland met with different fates. As far as the development of sociology is concerned, it needs to be known, with regard to its development in the years when Slovakia was experiencing "normalisation" that several Slovak sociologists studied at Polish universities (L. Falt’an, J. Stena, J. Bunčák and others, including interns such as J. Pichňa), who provided a better testimony about these events (e.g. J. Bunčák in an interview with V. Jancur, 2019) than the author of these lines, who received an extended study stay at the Institute of Philosophy of Sociology of the Polish Academy of Sciences (IFIS PAN) right at the start of the 1980s, at the time of Solidarnośc. Polish sociology, simply speaking, maintained constant contact with the development of world sociology on several levels by, among other things, publishing translations of titles of world sociological literature, both unaffordable, as well as unavailable in their original prints in our country (Czechoslovakia) due to censorship.

The development of Polish political science was more dramatic. UNESCO published the aforementioned publication in 1950, reflecting the World Political Organisation (IPSA) founded a year earlier. Poland was the only Central European country that had its own chapter in it dealing with the development of political sciences, with the names of dozens of political scientists, although today we consider many of them rather as sociologists, psychologists or lawyers, such as Ludwig Gumplowicz, Leon Pietrażycki, Ludwik Krzywicki and others; the publications already offer a number of references to the affinity of the then rich Polish sociology to the formation of the nascent political science (Langrod 1950). A paradox is that the same publication contained a chapter by other authors namely coming from Poland on the dialectical-materialist conception of political science (Schaff - Ehrlich, 1950) - authors who worked as professors at Polish universities until the 1970s. And it was Adam Schaff, with his ideological anti-empiricism as the main ideologue of the state party, who also tried to destroy even non-Marxist sociology (Mokrzycki, 1990, pp. 22 - 28), but especially the initiating Institute of Scientific Official Personnel Education (Instytut Kształczenia Kadr Naukowych) in 1950, who subjected the whole of Polish science to strong ideological pressure (Krauz, Mozer, Borowiec, Ścigaj, 2011, p. 65). As the founder of the Polish Society for Political Science (Polskie Towarzystwo Nauk Politycznych) (Gebethner, Markowski, 2002, p. 307), he, for a long time, ideologically influenced especially the development of political sciences in 
Poland, which thus became a pseudo-science, opportunistically defending the distorted political structure by methods of historical materialism and scientific communism (Konečný, 2020), which subsequently led to "hostility to political scientists, legitimising their origins in the ancien régimé" (Janowski, 2011, p. 12).

Nevertheless, islands of positive deviation endured in Poland in the sphere of political sciences, particularly from the mid-1950s, such as the initiatives of J. Kuroń, K. Modzelewski and others, and the Krzywego Koła Club in Warsaw, whose members included few political scientists, yet many sociologists (J. Chałasiński, Cz. Czapów, A. Gella, J. Karpiński, M. and S. Ossowski, A. Rudzińska, J. Strzelecki and others), including other influential representatives of Polish science and culture (Janowski, 2011). This was a signal of sociologists distancing themselves from Polish political science of that time, with its relationship to sociology developing differently to that in other Central European countries.

Although H.D. Klingemann (2002, p. 212) includes Poland (along with Yugoslavia) among the states where the political sciences were under weaker or milder ideological control than for example that in Czechoslovakia, throughout this whole region political sciences (if they could exist, at all, under such name) were so much distorted by Marxist theory that they were not at all able to capture trends in political science from around the world in the 1950s. "Due to the artificial obstacles to Czech [but also other Central European - note SK] social sciences, particularly political science, there are still sought corresponding terms and theoretical concepts used in developed political sciences in other countries" (Fiala, Schubert, 2007, p. 7) As written by A. Zybała, "Poland, too, lacks a strong model of public policy making and implementation. Thus, there is a lack of standards in the field of public deliberation, examination of public problems, programme analysis or evaluations" (Zybała, 2012a, p. 1). M. Potůček, too, back in 1994 wrote, at the beginning of the development of public policy in the Czech Republic and Slovakia, that "it is not sufficient for us simply to possess knowledge accumulated in public policy theory in times of the relatively peaceful evolution of contemporary capitalist societies ... We are forced to look for our own, original approaches, non-traditional solutions" (Potůček, 1994, p. 1). But the approach in Poland yet again differs in this aspect: we also encounter in this case a principled refusal to follow the achievements of political science and public policy theory in Western Europe and the USA. As J. Osiński explained: "the utility of Anglo-Saxon constructions is minor. With regard to a certain respect for the past, we can refer to some conclusions of $\mathrm{H}$. Lasswell or other 'classics', but I think that their current utility in Polish reality is slight" (Dyskusja, 2016, p. 18). 
Sociology, politology and public policy in development...

2 Relations between political sciences and sociology in the Czech Republic, Slovakia, and Poland since the 1990s

Developments after the revolutionary changes of the turn of the 1980s and 1990s in Central Europe in the field of political sciences followed different paths in the three countries under comparison. In the Czech Republic and Slovakia, the renewal of political science occurred partly thanks to the reactivation of teachers and students affected by its episode during the Prague Spring (even if some of them had since become involved in "scientific communism") and also their direct return to university departments (J. Škaloud, M. Kusý). Another innumerable but important circle was formed by dissident authors (M. Kusý, R. Kučera) or ex-exile authors (M. Novák, A. Müller) or the first graduates of political science studies in Western Europe (S. Abrahám). Also the first textbooks of political science after November 1989 shared a similar origin (Škaloud, 1991, Müller, 1991), though the next decade saw not only key translations of world authors (Heywood, 2002, Colebatch, 2005, Scruton, 1999, Sartori, 1994), but also numerous works by other domestic authors (Fiala, 1995, Kusý et al. 1998, Fiala, Schubert, 2000, Říchová, 2000, Rybárik, Lysý, Konečný, 2003, Pecka, 2000, etc.). In the Czech Republic and Slovakia, philosophers, historians and especially sociologists were significantly involved in building political sciences (Holzer, Pšeja, 2010, Rybář, 2010, Malová, Miháliková, 2002, Dvořáková, Kunc, 1994).

In this orientation of political science and in its development towards the emergence of interest in public policy it is necessary to take into account the fact that both key personalities in this field in the Czech Republic and Slovakia entered it as purely qualified sociologists: L'. Malíková, author of the first monograph on public policy in Slovakia (Malíková, 2003) and M. Potǔček, co-author and leader of the team of the first Central European collective monograph on public policy, which, by the way, was without participation of authors from Poland... (Potǔček et al., 2005). After all, almost half the authors' team of the first modern textbook of political science in Slovakia (Kusý et al., 1998) comprised sociologists (L. Malíková, S. Szomolányi) or at least sociologising political scientists (e. g. D. Malová). Therefore, in the Czech Republic and Slovakia, we can point to the direct influence of sociology on the emergence of public policy, while sociology plays the role of a more universal science in this relationship (Briška, 2010, p. 21).

The renewal of political science, as well as the formation of public policy, both in Slovakia and in the Czech Republic, took place in a rare symbiosis with the renewal of sociology. In the Czech context of the development of public policy, there is a strong standing of the influence of sociology, especially in its Prague centre around M. Poti̊ček, in contrast to the more political-oriented profile of the Brno centre around P. Fiala: the Prague 
line is thus, closer methodologically to the Francophone line, while the Brno line to the German line (Novotný, 2008, p. 14). The Prague francophone orientation was partly helped by the publishing activity of V. Novotný, but also by the political science approaches of M. Novák (2011), who shaped his political science profile during his lifelong work in francophone political science, while in Slovakia only L. Král'ová (2009) has pursued a similar orientation. At the same time, Slovak nascent public policy and its theory were closer to the Prague line of orientation.

The fundamental feature of the emerging theory of public policy in Poland was thus not just a prevailing rejection, or at least limited acceptance, of the achievements of this young science around the world - when R. Szarfenberg (2017) speaks literally about an impasse - but also the rejection of the starting points of political science: the development of political science in the past in Poland thus led to some scepticism also in relation to the traditions of the development of political science around the world. In Poland, however, the penetration of sociologising moments by political sciences is overall rejected, and public policy is included by some political scientists in the categories of "pseudo-political science” (Skarżyński, 2014). However, Polish political science is currently addressing its purification and methodological renewal in an environment of new challenges (Krzysztan, 2016).

On the other hand, W. Anjol states that "political science does not cease to be present also in Poland ... primus inter pares among the various social sciences, co-creating the science of public policy or contributing directly to it, as well" (Dyskusja, 2016, p. 23) and only more or less exceptionally some of the political scientists, through their original qualifications, get involved also in relation to public policy (e. g. R. Szarfenberg). In the Polish literature on the topic, W. Anjol adheres most to the standard Western European (Anglo-Saxon) understanding of public policy as a multidirectional and interdisciplinary science (Anjol, 2018).

3 Sources of public policy formation in Poland outside of political science and sociology

Poland, thus, in seeking its own conception of public policy theory, has chosen its own path, featuring a number of specifics:

1) A role similar to that played by sociology in fermenting political science leading to the emergence of public policy in the world, not just in the Czech Republic and Slovakia, was played by social policy in the country of our northen neighbours, which, as emphasised by e. g. R. Szarfenberg and is considered in Poland to be applied sociology (Dyskusja, 2016, p. 15). In this regard, we find examples of close links between social policy and public policy 
both in the Czech Republic (M. Potǔček) and Slovakia (e.g. M. Beblavý), similarly, as was also the case in Poland (R. Szarfenberg, M. Rymsza). K Frzystacki somewhere poetically called this relationshis "shimmering", M. Potůček perceives it as a continuum of aspects (Potuček, LeLoup, 2003, p. 21), whilst R. Szarfenberg writes that "these two areas of scientific reflection and research have remained intertwined with each other, since the state and the administration began to be seen as bearers of progress, as a means of solving societal problems, satisfying collective needs and increasing general wellbeing" (Szarfenberg, 2016, p. 47). Nevertheless, M. Grewiński asks "whether it is in the interest of Polish social policy to replace its traditional name with the term 'public policy', which still after all does not have its roots in Poland." (Grewiński, 2017, p. 89). A decree from the Minister of Higher Education \& Science dated 8 August 2011 (Journal of Laws 2011, No. 179 note 1065), which included public policy sciences among the social sciences, alongside sociology, psychology and pedagogy, was somewhere termed by M. Karwat with the Polish refrain: "peas and cabbage", or, as written by R. Szarfenberg, "it provoked an interesting discussion about the impact of this event on the situation of the hitherto unaccepted sciences on social policy" (Szarfenberg, 2017, p. 27). As P. Błędowski confirms, in Poland "in the environment of social politicians, we sometimes encounter, if not distaste to linking us with public policy, then at least reservations toward the localisation of this discipline" (Dyskusja, 2016, p. 17).

Since social policy in most Central European countries has a lead over public policy in its theoretical dimensions - for example, among others I. Tomeš, J. Auleytner, Zs. Ferge, I. Radičová, etc., with social policy being perceived here not just as an activity of the state, but also of the market and civil society (Konečný, Radičová, 2002, p. 251), it is perhaps becoming a possible starting point for shaping public policy: as far as this is not perceived merely as a policy for implementing state programmes financed from public funds. This, indeed, is how public policies in Poland are often understood, such as (state) demographic policy, family policy, housing policy, employment policy, etc. (Grzywna, Lustig, Mitręga, Stępień, Lampa, Zasępa, 2017). In our countries - the Czech Republic and Slovakia such analyses also focus on the activities of other, non-state, municipal, etc. actors, bringing our approaches closer to the framework of public policy, for example in such areas as educational policy (Veselý 2005, Kohoutek, Veselý, Špačková 2015), social policy (Čabanová, Munková 2003, Beblavý 2009), health policy (Háva 2005), but also forestry policy, for instance (Šálka, Dobšinská, Sarvašová, Štěrbová, Paluš 2017), etc.

2) In Poland, however, analyses of public programmes in various areas are sometimes considered to be at the heart of public policies. A key publication 
representing this direction is the monograph by A. Zybała, who writes in it about public policies / programmes, "understood as the process of analyses and design of solutions to social problems" (Zybała, 2012. p. 7). Other authors incline toward this view: "there is not a single public policy, but there are many sub-policies addressing collective problems" (Szatur, Jaworska 2018, p. 7). Zybała, like numerous other authors in this field, consciously uses the plural "public policies" (Zybała, 2012, p. 13, Zybała, 2012a, p. 3), not politics (W. Anjol in Dyskusja, 2017, p. 12) and not in the meaning of public policy in the singular of the noun, as used by L'. Malíková, M. Potůček and other Czech and Slovak authors. So, it is not just a grammatical difference. If we limit ourselves to public policy implemented by the state, we can say that each state implements a whole range of policies: economic, military, foreign, social, educational, etc., but policies can be implemented also with the participation of actors from non-state, public and private, for-profit and non-profit environment, i. e. in the open public space (Klus, 2007, Klus, 2008).

3) Another source of public policy formation in Poland has become the theory of public administration. Here some authors even identify public policy with administrative policy (Suwaj, Szczepankowski, 2009, p. 305), or with public administration. "Public policies can be understood as part of administrative policy... This dependence should be seen in the context of the continental model of public administration, in which administrative law and the standards of public administration used by it play an important role" (Izdebski, 2018, p. 224). Interestingly, some Polish authors are of the opinion that public policy is essentially a depoliticised administrative science (Ufel, 2016, p. 121).

The theory of public administration, as a starting point for profiling public policy in Poland, sometimes overlaps with approaches that rather follow up on the theories of governance.

4) Therefore, this approach is linked to a related approach which seeks its sources of public policy in governance theory, when, for example, M. Kulesza and D. Sześcilo write that "governance of public things is nothing more than a process of designing and implementing public policies" (Kulesza, Sześcilo, 2013, p. 12). It is significant that these authors see public policy as an empirical science: "administrative science and theory of administrative policy deal with real administration as it exists, that is the 'real world' (a world of social facts and their relevant assessment)" (ibidem: 15). In one of the first studies on public policy in Poland, its author J. Hausner wrote: "The implementation of public policies as the core of governance of public things is always an attempt to combine practical managerial (administrative) professionalism with the extended and transparent responsibility of public managers in relation to the addressees and users of their policy" (Hausner, 2007, p. 51). On the other hand, J. Osiński, in relation to the differences between governance of things and 
Sociology, politology and public policy in development...

public policy, writes that "these are two worlds that do not have an absolute fitting point" (Dyskusja, 2017, p. 28).

Sometimes this direction of the search for starting points of public policy in Poland is also associated with the legal tools of governance: "Public policy is a system of targets anchored in legal regulations, via which public authorities (constitutional and executive, central and territorial) determine for their implementation public tasks in individual areas" (Sześciło, 2014, p. 58).

5) A further source of inspiration for the formation of public policy in Poland (and specifically in Poland) has become praxeology as a science of the logic of human (purposeful) action, which originally developed in the environment of economic sciences (L. von Mises): praxeology is perceived as a science of effective activity that has a place between general theory of systems and, rather partially, economic science. Praxeology later found application in linguistics (translation theory), psychology, etc., and e. g. also in philosophy, where the Polish philosopher T. Kotarbiński contributed significantly to its development. Here in Poland, approaches to the formation of public policy theory are linked in part to its connection with public administration theory, while in the framework of public administration theory "it is asserted that there should be used the concept of efficient effectiveness as a praxeological category, and it is recommended to subordinate the organisation and functioning of administration to the praxeological directives of good work" (Maciejewski, Gierszewski, Brunka, 2012, p. 13), and there is space here also in which praxeology enters the discourse of public policy. "Management of public resources has the character of an activity in the praxeological understanding" (Truszkowska, Kurstak, 2012, p. 61). This approach is used in Poland, for example, in creating evaluation procedures for assessing public programmes belonging to a broader portfolio of contemporary Western, but also Czech and Slovak, public policy theory. In Slovakia, though, these have developed more in the economic (Gombitová, 2007) or managerial environment (Remr, 2013), while in Poland also in the economic environment (Surdej, 2008) or in contacts with management theory (Haber, Szałaj, 2008), but under praxeological inspiration.

4 Polish sociology and sociotechnology as a source of public policy formation in Poland

Thus, one of the few Polish sociologists involved in shaping Polish public policy from sociological positions and at the same time well-oriented in its current Western European approaches (as is the case of the Slovaks: L'. Malíková or M. Potůček) is K. Frzystacki (Frzystacki, 2017), defending positions similar to those of the non-political scientist and non-sociologist $\mathrm{J}$. Wożnicki, who considers sociology and its disciplines as one of the decisive 
sources of shaping the theory of public policy (Wożnicki, 2012, p. 144), even though many Polish authors lead a passionate discussion with him (Dyskusja, 2016).

On the other hand, it is necessary to perceive also the whole spectrum of sociological disciplines, which have achieved much greater diversity in Poland than in our region. R. Szarfenberg draws attention to "scientific traditions that are close to public policy in the history of our social sciences" (Dyskusja, 2016, p. 14), referring in particular to two truly authentic Polish sources of public policy, practically unrepresented among sources public policy formation elsewhere in the world: to praxeology (as discussed above) and sociotechnology, which have and still enjoyed strong Polish traditions.

Above all, though, we do not identify sociotechnology with social engineering (which in itself has many frames of reference - from ideological manipulation in totalitarian systems to the activities of hackers and trolls), which has also become criticised in Poland (Kubin, Kwaśniewski, 2000): in this way we get closer to a sociological understanding of sociotechnology, which in the interpretation of A. Podgórecki, as its foremost Polish and renowned world representative, consists in this difference: "Sociology deals with the formulation and verification of statements concerning links between the various elements of societal life; sociotechnology then deals with how to achieve the planned changes on the basis of this knowledge. In other words, sociology seeks to know social reality, sociotechnology, on the other hand, seeks to rationally change this reality" (Podgórecki, 1968, p. 7). Currently, this concept is supported in Poland particularly by authors from the interface of sociology and law. K. W. Frieske as a pupil of A. Podgórecki, paraphrasing H. Lasswell, writes that "knowledge of public policy is knowledge of how decision-making processes take place in public agendas" (Frieske, 2018, p. 18). For example, M. Karwat directly addresses issues of the relationship between social engineering and public policy (Karwat, 2018). Thus, in the Polish tradition, sociotechnology is strongly connected with the sociology of law, which was already included in Podgórecki's starting points (Podgórecki, 1968, pp. 55 - 70), and previously in the theory of law of L. Petrażický, whose contribution to public policy is dealt with by J. Kwaśniewski (2018, pp. 68-71). According to him, "sociotechnology is the original Polish equivalent of Anglo-Saxon public policy science" (ibidem, p. 67).

Analyses of this orientation began in the 1970s in the then Institute of Social Prophylaxis and Resocialisation of the University of Warsaw and continued after 1990 at its successor - the Faculty of Applied Social Sciences and Resocialisation, where research in this area was carried out under the title of public policy (Kwaśniewski, 2018, pp. 62-65) and which continues to the present. These approaches are used mainly in various areas of social policy (as 
Sociology, politology and public policy in development...

public policy), but also in its broader context of family policy (Racław, 2018), labour market policy (Giermanowska, 2018), penitentiary policy (Szczepaniak, 2018, Przesławski, 2018), anti-narcotics and anti-alcohol politics (Zamecka, 2018, Klingemann, 2018), citizenship policy (Arczewska, 2018), migration policy (Pawlak, 2018), religious policy (Libiszowska, Żółtkowska, 2018), etc.

We see a difference, for example, in the field of social policy, as it is presented in our region, where it is based on legal approaches (e. g. Tomeš, 2002): there is absent any stronger link to sociology of law, but often also to public policy. Sociotechnology, despite the translation of the basic work of A. Podgórecki (1968), did not find a wider resonance outside sociology, with the exception of J. Pichňa, who developed this sociological concept in the context of our region and published his approach as a book in 1989 (Pichňa, 1989). Pichňa formulated his position as follows: "Sociotechnology is a social science discipline. It shares a common subject with sociology - social reality and its departments (social systems). For this reason, sociotechnology, in its theoretical foundations, rests on sociological theories, such as theories of social change, social innovation, social immunology, etc. The methodological foundations of sociotechnology also include sociological methodology with its methods, especially in the implementation of the cognitive function of sociotechnology. When performing the design and construction function of sociotechnology, conventional sociological methods will no longer suffice. This is because sociology, i. e. sociological theory and methodology, are more focused on seeking insights into social reality, its cognition, and sociotechnology, i.e. sociotechnological theory and methodology, is, in its specification, more focused on positive change (designing) of social reality" (Pichňa, 2002, p. 25). Even though J. Pichña did not write it like that, we still consider his sociotechnology to be an (applied) sociological discipline, which has not yet been used in this region as an inspirational source in shaping public policy, for example by using its design function and focus on achieving changes in social reality, something which corresponds to the profile of public policy.

\section{Conclusion}

The formation of public policy theory in the Czech Republic and Slovakia since the mid-1990s copied a scenario akin to its formation in Western Europe and the USA, characterised in particular by the interaction between political sciences and sociology. In the Czech Republic and Slovakia, this process took place at an accelerated pace as a result of the delayed, but relatively rapid start of the development of political sciences, an advantage of which was, paradoxically, their lack of development in the preceding period. This restart benefited from the activity of a part of the sociology community, 
which previously had not been massively engaged in ideology; sociology managed its restart relatively quickly and without problems.

Although, sociology in the Czech Republic and Slovakia has restored its activities back in 1960s, but even in politically hard periods it has never ot given in fully to ideological pressure. However, its free development was enabled only after a change of political regime since 1990s. Under new circumstances, many Czech and Slovak sociologists were involved not only in practical politics but also in the development of newly established developing political science. This had considerable impact upon strengthening pluralistic approaches in this development and it led to natural development directed towards forming public policy within the framework of political sciences.

In Poland, sociology, despite difficult trials in its history, maintained its continuity and consistency throughout the post-war period, but political science went the opposite way. This created such a gulf between the two sciences that effectively made it impossible for them to cooperate directly in forming joint activities focusing on public policy. The influence of sociology on the profiling of public policy in Poland was only slightly lesser than in the Czech Republic and Slovakia, but very much more specific. This specificity is mainly an outcome of a larger, more numerous and thus internally more structured community of sociologists, but also political scientists in Poland, compared to these parameters of similar communities in the Czech Republic and Slovakia, which creates many more alternative solutions in the Polish environment. It is characteristic that each of these currents has its own adherents, but also its own critics. Therefore, although public policy in Poland, unlike its counterpart in the Czech Republic and Slovakia, differs in that in its mainstream it rejects not just the frames of reference of political science as well as the Western European-American tradition of public policy; it has been able to produce a number of alternative approaches to public policy profiling, based on other methodological starting points, including sociological starting points that have not yet found their relevance in the Czech Republic and Slovakia.

In this context, V. Novotný spoke of three "national configurations", whilst "the specific form of the configuration is determined primarily by two components, i. e. content and structure. The content of the configuration is given ... by the different specific approaches to the study of policy that exist in the given country. Their formation was heavily influenced by the traditional classification of the issue of policy under certain disciplines, the openness of the scientific community to adopt foreign approaches in the study of public policies, but also the demand for advice from political and administrative circles" (Novotný, 2008, p. 4). The above views on the formation of public policy in Poland, but also in Slovakia and the Czech Republic, are fully confirmed by the following features: we see here specifics in the inclusion of 
public policy in the system of sciences, differing approaches to the adoption of foreign models of public policy definition, etc. In this regard, we can also talk about less influential, but nonetheless present national Czech, Slovak, and Polish configurations.

For our reader, this implies, on the one hand, a certain caution when referring to Polish texts in the field of public policy, and, on the other hand, the possibility of being inspired by several new perspectives revealed by it as regards the profile of this young scientific discipline.

\section{References}

Alemann, U. (1998). Politische Soziologie als demokratietheoretische Nostalgie oder: Müssen wir die politische Soziologie neu erfinden? Alemann U., Czada R., (Hrsg.), Kongressbeiträge zur Politischen Soziologie, Politischen Ökonomie und Politikfeldanalyse. Fern Universität - Gesamthochschule Hagen. polis Nr. 39/1998: pp. 3 - 18 Antal, A. (2019). The (Re)Institutionalization of Hungarian Political Science. Openness and Closedness - Culture and Science in Hungary and the Soviet Bloc after Helsinki Conference.12 June 2019, Institute of Political History, Budapest. Retrieved 12 September, 2020, from:https://www.academia.edu/39537943/The_Re_Institutionalizatio n of Hungarian_Pol ical Science?email work card=title.

Aniol, W. (2018). Wielonurtowy i interdyscyplinarny charakter nauk o polityce publicznej. Szatur-Jaworska B., (red.) Polityki publiczne. Wybrane zagadnienia teoretyczne i metodologiczne. Warszawa. Wydawnictwo Universytetu Warszawskiego, 19 - 52.

Arczewska, M. (2018). Polityka obywatelska (polityka publiczna wobec społeczeństwa Obywatelskiego). Kwaśniewski J., (red.) Nauki o polityce publicznej. Monografia dyscypliny. Warszawa: Wydział Stosowanych Nauk Społecznych Uniwersytetu Warszawskiego, 169 191.

Beblavý, M. (2009). Sociálna politika. Bratislava, VŠZaSP sv. Alžbety, 167. Bourricaud, F. (1958). Science politique et sociologie. Réflexions d'un sociologue. Revue française de science politique, 8 (2), 249-276.

Briška, F. a kol. (2010). Teória a prax verejnej politiky, Banská Bystrica. Univerzita M. Bela, 282.

Colebatch, H. K. (2005). Úvod do policy. Brno, Barrister \& Principal, 141.

Čabanová B. Munková G. (2005). Sociální politika. Potůček, M. a kol. Veřejná politika, Praha, Sociologické nakladatelství, 245-276. 
Dewey, J. (1927). The Public and its Problem. An Essay in Political Inquiry. Chicago. Gateway Books [1946 reprint], 224.

Duverger, M. (1959). Méthodes de la science politique. Paris. PUF, 1959, 492.

Duverger, M. (1961). Introduction to the Social Sciences, London. Allen\&Urwin, 1961, 342.

Dvořáková, V. Kunc, J. (1994). O přechodech k demokracii, Praha, Sociologické Nakladatelství, 1994, 156.

Dyskusija. (2016). Wokót teoretycznych wyzwań $w$ naukach o polityce publicznej. Dyskusja z udziałem prof. Piotra Błędowskiego, prof. Włodzimierza Anioła, prof. Joachima Osińskiego, prof. Aleksandra Surdeja, prof. Ryszarda Szarfenberga i prof. Andrzeja Zybały jako moderatora. In: Studia z Polityki Publicznej, 1 (9), 11-44.

Falt’an, L'. (1995). Sociologický ústav - pät' rokov existencie“, Sociológia, 27 (3), 62-171.

Fiala, P. (1995). Německá politologie, Brno, CDK, 250.

Fiala, P. Schubert, K. (2000). Moderní analýza politiky: Úvod do teorií a metod policy Analysis, Brno, Barrister \& Principal, 170.

Fischer, F. Miller, G. J. and Sidney, M. S. (eds.) (2007). Handbook of public policy analysis: theory, politics and methods. Boca Raton, Fl. CRC Press: 642.

Frieske, K. W. (2018). Polityki publiczne: iluzje uniwersalnej racjonalności, Kwaśniewski J., (red.), Nauki o polityce publicznej. Monografia dyscypliny. Warszawa, Wydział Stosowanych Nauk Społecznych Uniwersytetu Warszawskiego, 7-22.

Frysztacki, K. (2017). Sfera publiczna - polityka publiczna: perspektywa amerikańska.

Studia Socjologiczne. 4 (227), 73 - 94.

Gebethner, S. Markowski, R. (2002). Political Science - Poland. Kaase, M. Sparschuh, V. A Wenninger., (eds.). Three social science disciplines in Central and Eastern Europe. Handbook on economics, political science and sociology (1989-2001). Berlin: Informationszentrum Sozialwissenschaften; GESIS Servicestelle Osteuropa, Collegium Budapest, Institute for Advanced Study, 306 - 321.

Giermanowska, E. (2018). Polityka rozwoju rynku pracy $i$ wspierania zatrudnienia, Kwaśniewski, J. (red.). Nauki o polityce publicznej. Monografia dyscypliny, Warszawa, Wydział Stosowanych Nauk Społecznych Uniwersytetu Warszawskiego: 229 - 265.

Gombitová, D. (2007). Úvod do monitorovania a evaluácie. Bratislava, Slovenská evaluačná spoločnost', 96.

Grewiński, M. (2017). Polska polityka spoleczna w latach 1989-2016 sukcesy i niepowodzenia. Ciura G., Kłos B., (eds.). Polityka społeczna w Polsce. Studia. 2(50), 59-92. 
Sociology, politology and public policy in development...

Grzywna, P. Lustig, J. Mitręga, M. Stępień-Lampa, N. Zasępa, B. (2017). Polityka spoteczna: rozważania o teorii i praktyce, Katowice, Wydawnictwo Uniwersytetu Śląskiego, 264.

Haber, A. Szałaj, M. (eds). (2008). Środowisko $i$ warsztat ewaluacji. Warszawa. Polska Agencja Rozwoju Przedsiębiorczości, 220.

Hausner, J. (2007). Polityka a polityka publiczna, Zarządzanie Publiczne. 1, $43-60$.

Háva, P. (2005). Zdravotní politika, Potůček, M. a kol. Veřejná politika, Praha, Sociologické nakladatelství, 311 - 352.

Heywood, A. (2002). Politologie, Praha, Eurolex Bohemia, 463.

Holzer, J. Pšeja, P. (2010). Twenty Years of Czech Political Science: On the Edge of

Maturity, Eisfeld, R. and Pal, A. Leslie (eds.) Political Science in Central East Europe. Diversity and Convergence. Opladen - Farmington Hills, MI, 103-118.

Izdebski, J. (2018). Realizacja polityk publicznych przez administracje publiczna, Zeszyty Naukowe KUL, 60 (1), 221-231.

Jančura, V. (2019). České univerzity vitajú slovenské talenty, Pravda.

Janišová, H. Ullrich, Z. (1998). Př́spěvek k dějinám československé sociologie let 1945-1949, Praha, Sociologické nakladatelství, 38.

Janowski, K. B. (2011). Politologii polskiej meandry, Przegląd Politologiczny, rok XVI, 1, 7-23.

Karwat, M. (2018). Inżynieria spoteczna. Interpretacja pojęcia, SzaturJaworska, B. (red.). (2018). Polityki publiczne. Wybrane zagadnienia teoretyczne i metodologiczne, Warszawa. Wydawnictwo Universytetu Warszawskiego, 113 - 128.

Klingemann, H. D. (2002). Political Science in Central and Eastern Europe: National Development and International Integration Kaase, M. Sparschuh, V. Wenninger, A. (eds.). (2002). Three social science disciplines in Central and Eastern Europe. Handbook on economics, political science and sociology (1989-2001), Berlin. Informationszentrum Sozialwissenschaften; GESIS Servicestelle Osteuropa; Collegium Budapest, Institute for Advanced Study, 206 212.

Klingemann, J. I. (2018). Iluzja polityki spolecznej opartej na dowodach naukowych. Przyktad zjawiska uzależnienia od alkoholu, Kwaśniewski, J. (red.). (2018) Nauki o polityce publicznej, Monografia dyscypliny, Warszawa, Wydział Stosowanych Nauk Społecznych Uniwersytetu Warszawskiego, 312 - 328.

Klobucký, R. (2009). Štyridsat' rokov časopisu Sociológia, Sociológia, 4 (1), 52-82. 
Klus, M. (2007). Verejná politika. Priestor. Efektívnost'. Nástroje. Nové výzvy, Sládkovičovo, Vysoká škola, 139.

Klus, M. (2008). Aktéri verejnej politiky, Štrukturalizácia, Vol'ba, Banská Bystrica, Univerzita M. Bela, 145.

Kohoutek, J. Veselý, A. Špačková, Z. et al. (2015). Vzdělávací politika, Brno, Masarykova univerzita, 472.

Konečný, S. Radičová, I. (2002). Sociálna politika vo svete a u nás, Tokárová, A. a kol. (2002). Sociálna práca, Prešov, Filozofická fakulta Prešovskej univerzity, $249-274$.

Král'ová, L. (2009). Substancia a genéza verejnej politiky, Král'ová, L. (ed.). (2009). Genéza a tvorba verejnej politiky na Slovensku, Prešov, KMSystém, $23-81$.

Kraus-Mozer, B. Borowiec, P. Ścigaj, P. (2011). Kim jesteś, politologu? Historia $i$ stan dyscypliny $w$ Polsce, Kraków, Wydawnictwo Uniwersytetu Jagiellońskiego, 332.

Krzysztan, B. (2016). Anthropos u żródel polityczności. Anachroniczność $i$ potrzeba imersji $w$ naukach politycznych, Krzysztan, B. Ufel, W. Zieliński, M. Polityka/Polityczność. Granice dyskurzu, Wrocław, Oficyna Wydawnicza ATUT - Wrocławskie Wydawnictwo Oświatowe, 13-39.

Kubin, J. Kwašniewski, J. (red.). (2000). Socjotechnika. Kontrowersje, Rozwój, Perspektywy, Warszawa. Instytut Profilaktiki Społecznej i Resocializacji Universytetu Warszawskiego - Polskie Towarzystwo Socjologiczne, 305.

Kulesza, M. Sześciło, D. (2013). Polityka administracyjna i zarządzanie publiczne, Warszawa. Wolters Kluwer, 175.

Kusý, M. a kol. (1998). Politológia: Vybrané kapitoly, Bratislava, Univerzita Komenského, 181.

Kwaśniewski, J. (2018). Źródła nauk o polityce publicznej: polityka prawa isocjotechnika. Kwaśniewski, Jacek. (red.): Nauki o polityce publicznej. Monografia dyscypliny. Warszawa: Wydział Stosowanych Nauk Społecznych Uniwersytetu Warszawskiego, 61 - 96.

Laiferová, E. Mistríková, L'. (eds.). (2014). Sociológia v ére normalizácie program, funkcie, perspektivy, Bratislava, Stimul, 275.

Langrod, G. L. (1950). Political Science in Poland, Salvadori M., (red.), Contemporary Political Science. A Survey, Methods, Research and Teaching. Publication No. 126. Paris. UNESCO, 178 - 195.

Libiszowska-Żółtkowska, M. (2018). Polityka wyznaniowa, Kwaśniewski, J. (red.).(2018). Nauki o polityce publicznej. Monografia dyscypliny. Warszawa. Wydział Stosowanych Nauk Społecznych Uniwersytetu Warszawskiego, $266-287$. 
Sociology, politology and public policy in development...

Maciejewski, T. Gierszewski, J. Brunka, M. (2012). Z problemów administracji. Wybrane zagadnienia administracji publicznej, Chojnice, Powszechna Wyższa Szkoła Humanistyczna, 156.

Malíková, L'. (2003). Verejná politika. Aktéri a procesy, Bratislava. Univerzita Komenského, 120.

Malová, D. Miháliková, S. (2002). Political Science - Slovakia, Kaase, M. Sparschuh, V. Wenninger, A., (eds.) „Three social science disciplines in Central and Eastern Europe: Handbook on economics, political science and sociology (1989-2001)“, Berlin: Informationszentrum Sozialwissenschaften; GESIS Servicestelle Osteuropa; Collegium Budapest, Institute for Advanced Study, 343 - 357.

Mokrzycki, U. E. (1990). Socjologia w filozoficznym kontexcie, Warszawa, Instytut Filozofii i Socjologii PAN, 101.

Možný, I. (2004). Brněnská anomálie? Brněnská sociologie 1963 až 1989 subjektivní Historie, Sociologický časopis, (40) 5, 573-595.

Muller, P. (2018). Les Politiques Publiques, Paris. Presses Universitaires de France: 72.

Müller, A. (2009). Úvod do vědy o politice, Praha, Lunarion, 117.

Musil, J. (2004). Poznámky o české sociologii za komunistického režimu, Sociologický časopis, (40) 5, 609-622.

Nešpor, Z. R. (2014). Dějiny české sociologie, Praha, Academia, 668.

Novák, M. a kol. (2012). Úvod do studia politiky, Praha, Sociologické nakladatelství, 783.

Novotný, V. (2006). Francouzská tradice studia veřejných politik: Možné inspirace, Němec J., Šůstková M., (eds.). III. Kongres českých politologů, Olomouc 8.-10. 9. 2006. Praha, Olomouc, Česká společnost pro politické vědy, 896 - 906.

Novotný, V. (2008). Studium veřejných politik v komparativní perspektivě, ČLOVĚK - Časopis pro humanitní a společenské vědy, 10, 10.

Paruch, W. (2015). Konsekwencje definiowania myśli politycznej dla kwestionariusza badań politologicznych, Humanities and Social Sciences, 22 (1), 157 - 174.

Pawlak, M. (2018). Polityki publiczne wobec migracji, Kwaśniewski, J. (red.). (2018). Nauki o polityce publicznej. Monografia dyscypliny. Warszawa. Wydział Stosowanych Nauk Społecznych Uniwersytetu Warszawskiego, 288 - 312.

Pecka, E. (2000). Politická kultura v ČR, Praha, Vysoká škola ekonomická v Praze, 221.

Pecka, E. (2011). Proces tzv. normalizace v české sociologii, Historická sociologie, $3(1), 7$ - 94.

Petrusek, M. Kilias, J. (2011). Miloslav Petrusek o historické sociologii, dějinách a literatuře, Historická sociologie, 3 (2), 115 - 120. 
Pichňa, J. (1989), Sociológia a spoločenská prax (Úvod do sociotechniky), Bratislava. Práca, 280.

Pichňa, J. (2002). Úvod do sociotechniky, Trnava, Fakulta humanistiky Trnavskej univerzity, 263.

Podgórecki, A. (1968). Základy sociotechniky, Praha, Svoboda, 141.

Potůček, M. (1994). Zrod veřejné politiky jako vědního odboru a jako sociální praxe, Potůček, M. Purkrábe, M. Vavroušek, J. et all. (1994). Zrod teorie veřejné politiky $v$ České republice, Praha, Institut sociologických studií, $1-16$.

Potůček, M. a kol. (2005). Veřejná politika, Praha, Slon, 399.

Potůček, M. LeLoup, L. (2003). Approaches to Public Policy in Central and Eastern Europe, Potůček, M. LeLoup, L. Gyorgy, J. Váradi, L., Public Policy in Central and Eastern Europe. Theories, Methods, Practices, Bratislava, NISPAcee, 11-23.

Przesławski, T. (2018). Pozycja i funkcje polityki penitencjarnej w naukach o polityce Publicznej, Kwaśniewski J., (red.), Nauki o polityce publicznej. Monografia dyscypliny. Warszawa: Wydział Stosowanych Nauk Społecznych Uniwersytetu Warszawskiego, 393 - 411.

Racław, M. (2018). Polityka rodzinna: od taktyki ku strategii ładotwórczej, Kwaśniewski, Jerzy (red.) 2018. Nauki o polityce publicznej. Monografia dyscypliny, Warszawa, Wydział Stosowanych Nauk Społecznych Uniwersytetu Warszawskiego, 192-228.

Remr, J. (2013). Srovnání vybraných př́stupů k realizaci evaluací, Evaluační teorie a praxe, 1 (1), 29-52.

Roško, R. (1995). Pred tridsiatimi rokmi, Sociológia, 27 (3), 154-158.

Rybárik, J. Lysý, J. Konečný, S. (2003). Politológia, Bratislava, STU, 153.

Rybár, M. (2010). Political Science in Slovakia: Hesitant Emergence from Elementary Problems, Eisfeld R., Pal L. A., (eds.)., Political Science in Central-East Europe. Diversity and Convergence, Opladen Farmington Hills, MI, 267-280.

Říchová, B. (2000). Přehled moderních politologických teorií, Praha, Portál, 303.

Salvadori, M. (red.). (1950). Contemporary Political Science. A Survey, Methods, Research and Teaching, Publication No. 126. Paris: UNESCO, 713.

Sartori, G. (1993). Teória demokracie, Bratislava, ARCHA, 512.

Scruton, R. (1999). Slovník politického myšlení, Brno, Atlantis, 188.

Sedláček, J. a kol. (2004). Kulatý stůl: Česká sociologie v letech 1965-1989, Sociologický Časopis, 40 (5), 695-740.

Schaff, A. Ehrlich, S. (1950). The Concept of Dialectical Materialism in Political Science“, Salvadori, M. (red.) (1950). Contemporary 
Sociology, politology and public policy in development...

Political Science. A Survey, Methods, Research and Teaching. Publication No. 126. Paris. UNESCO, 327-336.

Skarzyňski, R. (2014). Monizm i pluralizm w rozwoju dyscypliny nauki: politologia $i$ Pseudopolitologia, Skarzyński, R. (ed.). (2014). Przedmiot poznania politologii. Podstawy dyscypliny nauki, Białystok, Temida, 9 - 48.

Skovajsa, M. Balton, J. (2014). Sociology in the Czech Republic, London, Palgrave Macmillan, 150.

Surdej, A. (2008). Metoda analizy kosztów i korzyści: imperatyw efektywności w politykach publicznych, Haber, A. Szałaj, M. (red.). (2008). Środowisko i warsztat ewaluacji, Warszawa, Polska Agencja Rozwoju Przedsiębiorczości, 109-126.

Suwaj, P. J. Szczepankowski, R. (2009). Polityka publiczna jako instrument Administrowania, Kudrycka ,B. Peters ,G. Suwaj, P. J. (red.). (2009). Nauka administracji, Warszawa, Wolters Kluwer, 303 - 311.

Szarfenberg, R. (2016). Polityka publiczna - zagadnienia i nurty teoretyczne, Studia z Polityki Publicznej, 9 (1), 45-75.

Szarfenberg, R. (2017). Nauki o polityce publicznej - szansa ma rozwój czy ślepa uliczka dla badań polityki społecznej?, Polityka Społeczna, 518519 (5-6), 27-31.

Szatur-Jaworska, B. (red.). (2018). Polityki publiczne. Wybrane zagadnienia teoretyczne i Metodologiczne, Warszawa. Wydawnictwo Universytetu Warszawskiego, 259.

Szczepaniak, K. (2018). Wybrane problemy i kierunki polityki penitencjarnej. Kwaśniewski, J. (red.). (2018). Nauki o polityce publicznej. Monografia dyscypliny. Warszawa. Wydział Stosowanych Nauk Społecznych Uniwersytetu Warszawskiego, 357-392.

Sześciło, D. (2014). Polityka publiczna i rola administracji $w$ jej tworzeniu, Sześciło, D. Administracja i zarządzanie publiczne. Nauka o współczesnej administracji, Warszawa. Stowarzyszenie Absolwentów Wydziału Prawa i Administracji Uniwersytetu Warszawskiego, 324.

Szomolányiová, S. (1995). Metareflexia histórie SÚ SAV, Sociológia, 27 (3), 158-162.

Šálka, J. Dobšinská, Z. Sarvašová, Z. Štěrbová, M. Paluš, H. (2017). Lesnícka politika, Zvolen, Technická univerzita vo Zvolene, 275.

Škaloud, J. (1991). Úvod do politologie, Praha, Vysoká škola ekonomická, 120.

Tarde, G. (1989). L'opinion et la foule, Paris. Les Presses universitaires de France, 184.

Tomeš, I. et alli. (2002). Sociální správa, Praha, Portál, 304.

Torgerson, D. (2007). Promoting the Policy Orientation: Lasswell in Context, Fischer F., Miller, G. J. Sideny, M. S. (eds.). (2007). Handbook of 
public policy analysis: theory, politics and methods, Boca Raton, Fl. CRC Press, 15 - 28.

Truszkowska-Kurstak, M. (2012). Ewaluacja ekonomiczna w świetle podstawowych zasad gospodarowania środkami publicznymi, Zarządzanie Publiczne, 17 (1), 51-62.

Ufel, W. (2016). Apolityczność jako gnoza nowoczesności. Rekonstrukcja pojęcia polityczniości $w$ teorii i praktyce demokracji, Krzysztan, B.,

Ufel, W. Zieliński, M. (2016). Polityka/Polityczność, Granice dyskurzu, Wrocław, Oficyna Wydawnicza ATUT - Wrocławskie Wydawnictwo Oświatowe, 101-123.

Uhlerová, M. (2013). Záujmové skupiny v teórii politiky, Banská Bystrica. Belianum, 148.

Veselý, A. (2005). Vzdělávací politika, Potůček, M. a kol. (2005) Veřejná politika, Praha, Sociologické nakladatelství, 277 - 310.

Wožnicki, J. (2012). Nowa dyscyplina - nauki o polityce publicznej usytuowana $w$ dziedzinie nauk społecznyc, Nauka. (1), 133-151.

Woźnicki, J. (2015). Nauki o polityce pu blicznej - cztery lata rozwoju $w$ symbiozie z Politologia, Politeja, 36 (5), 9 - 25.

Zamecka, J. (2018). Środki prawnokarne $w$ przeciwdziałaniu problemom narkotykowym, Kwaśniewski, J. (red.). (2018). Nauki o polityce publicznej. Monografia dyscypliny. Warszawa. Wydział Stosowanych Nauk Społecznych Uniwersytetu Warszawskiego, 99 - 141.

Zybała, A. (2012). Polityki publiczne, Warszawa, Krajowa Szkoła Administracji Publicznej, 377. 